\title{
Influence of Sowing Depth in the Emergence of Urochloa and Panicum
}

\author{
Geisilene Ribeiro Schmoeller ${ }^{1}$, Elonha Rodrigues dos Santos ${ }^{2}$, Kledson de Oliveira Almeida ${ }^{1}$, \\ Fabrício Leonardo Alves Ribeiro ${ }^{2}$, Andrezza Miguel da Silva ${ }^{2}$, Zêni Lehrbarch Martins ${ }^{2}$ \\ \& Jhonatan Monteiro de Oliveira ${ }^{3}$ \\ ${ }^{1}$ Pós-graduação Lato sensu em Ciências do Solo e Produção Vegetal, Faculdade da Amazônia, Vilhena, \\ Rondônia, Brazil \\ ${ }^{2}$ Professor dos Cursos de Agronomia e Zootecnia, Faculdade da Amazônia, Vilhena, Rondônia, Brazil \\ ${ }^{3}$ Federal Institute of Rondônia, Campus Colorado do Oeste, Rondônia, Brazil \\ Correspondente: Elonha Rodrigues dos Santos, Professor dos Cursos de Agronomia e Zootecnia, Faculdade da \\ Amazônia, Vilhena, Rondônia, Brazil. E-mail: elonharodrigues@gmail.com
}

\author{
Received: February 9, $2019 \quad$ Accepted: April 3, $2019 \quad$ Online Published: May 31, 2019 \\ doi:10.5539/jas.v11n7p231 URL: https://doi.org/10.5539/jas.v11n7p231
}

\begin{abstract}
Sowing depth of forage seed is an important factor in seed germination and emergence and varies according to crop. Ideal sowing should be performed at a depth sufficient to promote rapid and uniform germination, with minimal reserve expenditure and facilitating nutrient uptake by the plant. The objective of this study was to evaluate the influence of sowing depth on seed germination of forage species in the field. The experiment was implemented in September 2018. The design was completely randomized in a $4 \times 4$ factorial scheme with four replicates, being the first factor four forage cultivars: Urochloa 'Xaraés'; Urochloa 'Piatã'; Urochloa ruziziensis and Panicum maximum 'Mombaça'; and the second factor four sowing depths: 0; 4; 7 and $10 \mathrm{~cm}$. The variables evaluated were initial emergence; emergence at 10 days after sowing; emergence at 21 days after sowing and emergence speed index. Seeding at $0 \mathrm{~cm}$ provides greater emergence of seedlings for Urochloa brizantha 'Piatã', Urochloa brizantha 'Xaraés', Urochloa ruziziensis and Panicum maximum 'Mombaça'. Seedling emergence reduced when sowing was performed at greater depths $(4,7$, and $10 \mathrm{~cm})$. If necessary, Urochloa brizantha 'Piatã' should be sown up to $7 \mathrm{~cm}$. The sowing at $10 \mathrm{~cm}$ depth is not recommended for any of the studied cultivars.
\end{abstract}

Keywords: Brachiaria brizantha, Xaraés, Piatã, Mombaça

\section{Introduction}

Pastures are considered the main feed source for Brazilian livestock, which is based on the extensive production system. The main forages that have been used in pastures are the genera Urochloa (Braquiária) and Panicum, which are the most important sources of nutrients in animal feed, providing energy, proteins, fibers, minerals and vitamins (Euclides et al., 2016). In addition, grasses promote improvements in soil profile, increasing porosity, and resulting in greater soil exploration by the roots (Mendonça et al., 2013; Almeida Júnior et al., 2017; Chioderoli, 2010).

Seeds are the agricultural input of prime importance, because it represents the basis of the productive process, as it conveys the genetic characteristics of the cultivar to the field, however, high physiological quality seeds are needed to obtain a uniform stand (Santos et al., 2012). In addition, environmental conditions, like temperature, humidity and soil oxygen, can influence the germination and the development of forage seeds. The sowing depth may influence these factors, being relevant in pasture formation (Oliveira \& Scivittaro, 2007; Zuffo et al., 2014).

Sowing forages in greater depths or at the soil surface are frequent in pasture formation in Brazil, mainly in the implantation of the crop-livestock system, as the seeds are added in the fertilizer box and sown at greater depths (Geier et al. , 2018). When sown on the soil surface after the initial development of the main crop (corn, soybean etc.), not following the recommendation of indicated depth (Silva Filho, 2018). Great variation in the forage sowing depth in the literature, ranging from 1 to $10 \mathrm{~cm}$ (Foloni et al., 2009). According to Shanmuganathan and Benjamin (1992), the ideal seeding depth should promote rapid and uniform germination, with minimal reserve expenditure, and facilitating nutrient uptake. 
The germination test in the laboratory consists of determining the maximum potential of germination, as it is performed under optimum conditions, however, this may overestimate the seeds physiological potential, as seeds from a same lot with similar germination may have inferior performance in the field regarding the percentage and uniformity of seedling emergence due to seed vigor (Marcos Filho, 2015). Thus, field emergence tests are a indicative of seed vigor, whereas germination and seedlings survival are directly linked to the seeds vigor.

In light of the foregoing, the objective was to evaluate the emergence of forage seedlings (Urochloa brizantha 'Piatã', Urochloa brizantha 'Xaraés', Urochloa ruziziensis and Panicum maximum 'Mombaça') in different sowing depths in the field.

\section{Methods}

The experiment was carried out on September 20, 2018, in $1 \mathrm{~L}$ pots filled with soil collected in an agricultural area in the $20 \mathrm{~cm}$ to $40 \mathrm{~cm}$ layer of a dystrophic red-yellow Latosol (EMBRAPA, 2009) in Juara, Mato Grosso, Brazil.

The experimental design was completely randomized in a $4 \times 4$ factorial scheme with four replicates, whereas the first factor refers to forage cultivars (Urochloa brizantha 'Xaraés', Urochloa brizantha 'Piatã', Urochloa ruziziensis and Panicum maximum 'Mombaça'), and the second factor refers to seeding depth: 0;4; 7 and $10 \mathrm{~cm}$. Twenty five seeds were sown per replicate of each forage, totaling 100 seeds per treatment. The seeds were obtained commercially from a 2017/2018 lot.

The variables analyzed were: initial emergence (IE), through seedling emergence test in the field; emergence at 07 days after sowing (DAS), direct counting of emerged seedlings and values expressed as percentage (Brazil, 2009); emergence at 10 DAS (E10DAS), performed by seedling emergence in field test, at 10 DAS, emerged seedlings were counted and values transformed into percentage; emergence at 21 DAS (E21DAS), performed by seedling emergence in field test with evaluation at 21 DAS, counting the seedlings emerged and values expressed as percentage; and emergence speed index (ESI), performed in conjunction with the seedlings emergence test, wherein seedlings were counted daily from the third day after the experiment set up until 21 DAS (germination stabilization). The IMC was estimated by summing the number of plants emerged each day, divided by the number of days after sowing, according to Maguire $(1962)$, by the formula: $\mathrm{ESI}=(\mathrm{E} 1 / \mathrm{N} 1)+$ $(\mathrm{E} 2 / \mathrm{N} 2)+\ldots+(\mathrm{En} / \mathrm{Nn})$, where, ESI $=$ emergenc speed index; E1, E2, En = number of emerged plants, in the first, second and last count; N1, N2, Nn = number of days after sowing at the first, second and last count. To determine the germination percentage, the seedling emergence was counted, and the data were transformed to percentage.

The data were submitted to analysis of variance $(p<0.05)$ test $F$. The mean values were compared by bar of experimental error by the Tukey test $(\mathrm{p} \leq 0.01)$.

\section{Results}

There was interaction between forage and sowing depths for all variables analyzed: initial emergence, emergence at 10 DAS, emergence at 21 DAS and emergence speed index (ESI) (Table 1).

Table 1. Summary of the joint variance analysis of the characteristics: initial emergence (IE), emergence at 10 days (E10 DAS), emergence at 21 days (E21 DAS) and ESI of the forages Urochloa brizantha 'Piatã', Urochloa brizantha 'Xaraés', Urochloa ruziziensis and Panicum maximum 'Mombaça' sown at four seeding depths, Juara-MT, Brazil, 2018

\begin{tabular}{llllll}
\hline \multirow{2}{*}{ Source of Variation } & \multirow{2}{*}{ DF } & \multicolumn{4}{c}{ Mean Square } \\
\cline { 3 - 5 } & & IE & E10 DAS & E21DAS & ESI \\
\hline Cultivar (C) & 3 & $2204.66^{* *}$ & $3390.00^{* *}$ & $3120.25^{* *}$ & $22.01^{* *}$ \\
Depth (D) & 3 & $2458.00^{* *}$ & $4482.00^{* *}$ & $4590.25^{* *}$ & $27.33^{* *}$ \\
C $\times$ D & 9 & $268.44^{* *}$ & $257.77^{* *}$ & $265.13^{* *}$ & $2.04^{* *}$ \\
Error & 48 & 64.83 & 107.66 & 122.41 & 0.50 \\
\hline CV $(\%)$ & & 56.50 & 41.51 & 41.46 & 39.97 \\
Mean & 14.25 & 25.00 & 26.68 & 1.78 \\
\hline
\end{tabular}

Note. ${ }^{* *}$ Significant at $1 \%$ by the $\mathrm{F}$ test. 


\subsection{Initial Emergence}

The initial emergence for all tested forages decreased as seeding depth increased (Figure 1).

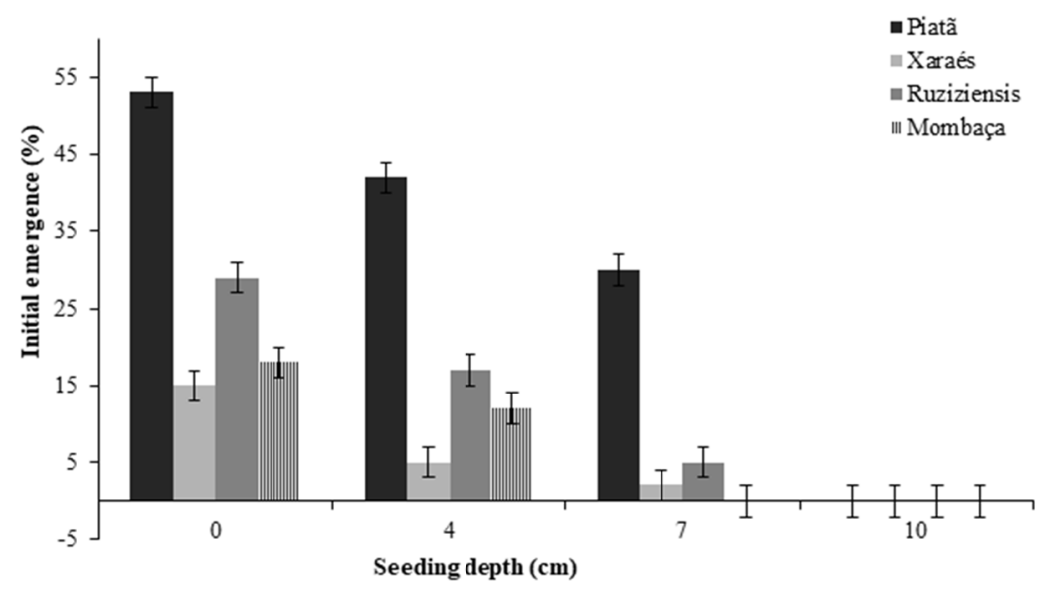

Figure 1. Initial emergence of the forages Urochloa brizantha 'Piatã', Urochloa brizantha 'Xaraés', Urochloa ruziziensis and Panicum maximum 'Mombaça' sown in four seeding depth, Juara-MT, Brazil, 2018

The Urochloa 'Piatã' presented a greater initial emergence and differed from the other cultivars for all tested depths. This cultivar reached maximum germination of $58 \%$ and minimum of $0.068 \%$ at depths of $0 \mathrm{~cm}$ and at $10 \mathrm{~cm}$, respectively, at seven days after sowing.

The other cultivars ('Xaraés', 'Ruziziensis', and 'Mombaça') did not differ among themselves and reached maximum germination of $20 \%$ when sown at $0 \mathrm{~cm}$ of depth and a value almost null to $10 \mathrm{~cm}$. Possibly, seeds sown at lower depths spent less reserves, ensuring greater germination, while those sown at greater depths had to break up to $6.0 \mathrm{~cm}$ of soil, depleting the seed reserve, thus reducing germination.

\subsection{Emergence at 10 DAS}

At 10 days after sowing, the cultivars were divided into two significant groups, being 'Piatã' superior to the group composed by the other forages ('Xaraés', 'Ruziziensis' and 'Mombaçsa') (Figure 2). Also, 'Piatã' sown at $0 \mathrm{~cm}$ obtained higher germination rate $(63 \%)$, whereas the other cultivars obtained a $35 \%$ emergence at the same seeding depth. There was a $28 \%$ of emergence reduction of the second cultivars group compared to 'Piatã', at 0 cm depth.

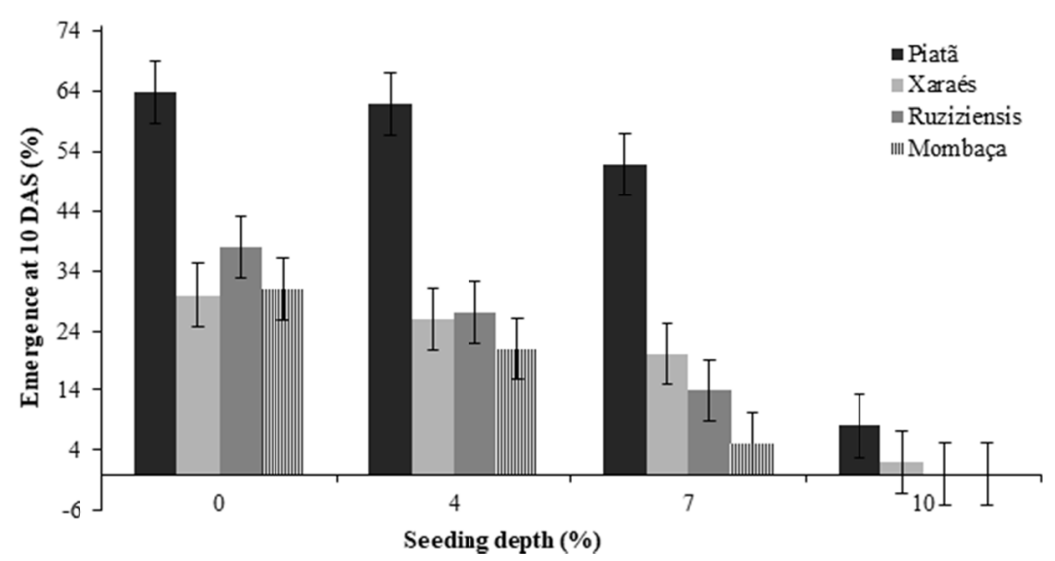

Figure 2. Emergence at 10 days after sowing (DAS) of forages Urochloa brizantha 'Piatã', Urochloa brizantha

'Xaraés', Urochloa ruziziensis and Panicum maximum 'Mombaça' sown in four seeding depth, Juara-MT, Brazil, 2018 
As the seeding depth increased $(4,7$, and $10 \mathrm{~cm})$, the 'Piatã' remained equidistant from the other cultivars (Figure 2). In the $4 \mathrm{~cm}$ depth, $60 \%$ difference between these cultivars, and $75 \%$ difference in the depth of $7 \mathrm{~cm}$ were observed, showing the superiority in the germination of 'Piatã'.

At the depth of $10 \mathrm{~cm}$, germination was only observed for 'Piatã' (8\%) and 'Xaraés' (2\%), with no germination at 10 DAS for 'Ruziziensis' and 'Mombaça'.

\subsection{Emergence at 21 DAS}

The emergence at 21 DAS was also maximal when sown at $0 \mathrm{~cm}$ (Figure 3), following the trend of the initial emergence and emergence at 10 DAS, for all cultivars. There was a gradual reduction in emergence at 21 DAS as the sowing depth increased.

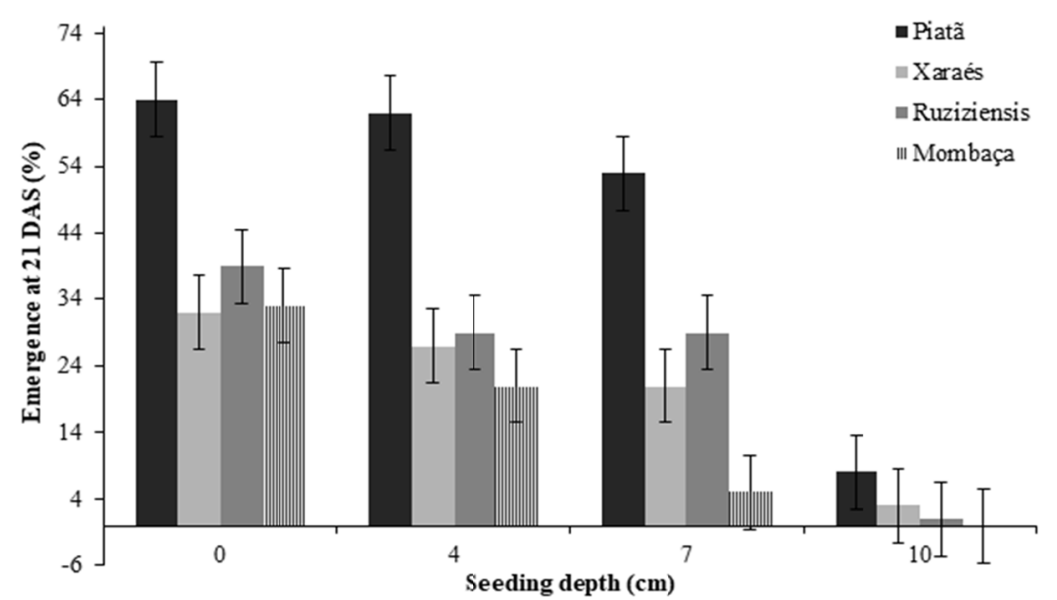

Figure 3. Emergence at 21 days after sowing (DAS) of forages Urochloa brizantha 'Piatã', Urochloa brizantha 'Xaraés', Urochloa ruziziensis and Panicum maximum 'Mombaça' sown at four seeding depths, Juara-Mato Grosso, Brazil, 2018

The 'Piatã' remained superior to the other forages ('Xaraés', 'Ruziziensis' and 'Mombaça') in the depths of 0; 4. and $7 \mathrm{~cm}$ deep; and equated to these at depth of $10 \mathrm{~cm}$. Still in the depth of $10 \mathrm{~cm}$, the emergence was practically null for 'Mombaça' and lower, on average, to $5 \%$ for the other cultivars.

There was no difference between 'Xaraés', 'Ruzizziensis' and 'Mombaça' when sown at 0 and $4 \mathrm{~cm}$ depth. However, the emergence of 'Mombaça' was reduced when sown at 7 and $10 \mathrm{~cm}$. The forages average for emergence at 21 DAS $35.5,28,25$, and $2 \%$, at depths of $0,4,7$, and $10 \mathrm{~cm}$, respectively.

For 'Piatã', there was a $56 \%$ reduction between the sowings at 0 and $10 \mathrm{~cm}$ of depth. This cultivar was not affected when sown up to $7 \mathrm{~cm}$. 'Piatã' showed emergence of 64,62 and $53 \%$ in the depths of 0,4 , and $7 \mathrm{~cm}$ depth, respectively, achieving the minimum germination rate established by the Brazilian legislation, which is $40 \%$.

The 'Xaraés', U. ruziziensis and 'Mombaça' did not emerge satisfactorily in any of the studied depths, according to Brazilian legislation. This low emergence is probably related to the low seed vigor. The maximum emergence for these cultivars was only $34.6 \%$ at $0 \mathrm{~cm}$ of sowing.

Adopting the recommended sowing depth is really important in the seed emergence process, regardless of the forage, as the emergence reduces significantly as the seeding depth increases (Figure 3).

\subsection{Emergence Speed Index (ESI)}

The ESI presented different results among the cultivars studied (Figure 4). Reduction in ESI was observed for all cultivars as sowing depth increased. 


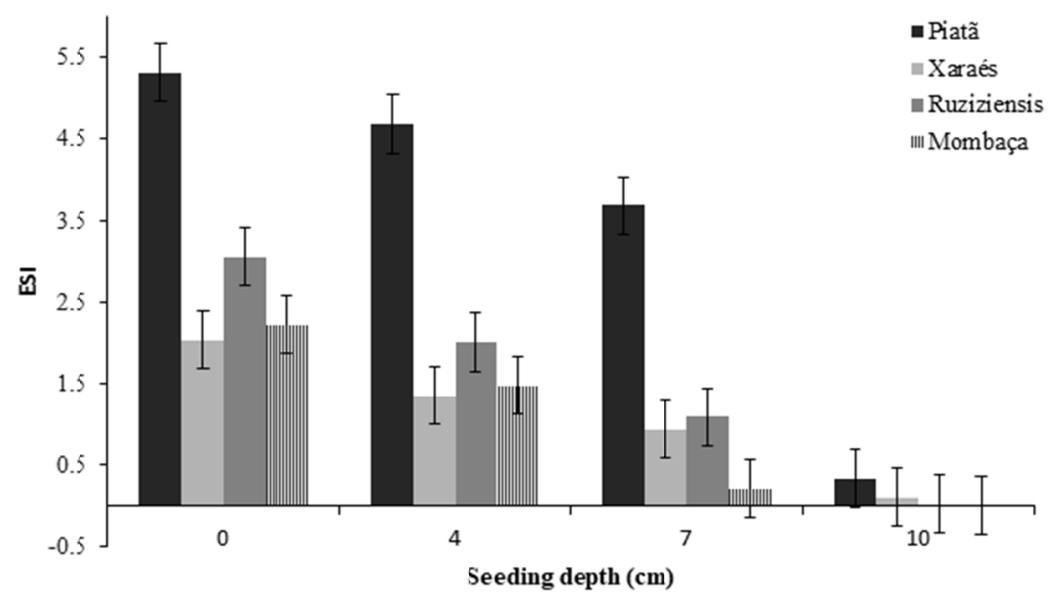

Figure 4. Emergence speed index (IVE) of forages Urochloa brizantha 'Piatã', Urochloa brizantha 'Xaraés', Urochloa ruziziensis and Panicum maximum 'Mombaça' sown in four seeding depths, Juara - Mato Grosso, Brazil, 2018

In the sowing at $0 \mathrm{~cm}$ of depth (at soil surface), the 'Piatã' showed maximum value for ESI of 5.31 . The group composed of cultivars 'Xaraés', 'Ruziziensis' and 'Mombaça' presented maximum ESI value at $0 \mathrm{~cm}$ depth. At 4 $\mathrm{cm}$ depth, 'Piatã' maintained the ESI high (4.8), not differing from the sowing at $0 \mathrm{~cm}$. For 'Xaraés', 'Ruziziensis' and 'Mombaça' reduced the ESI by $40 \%$ when compared to sowing at $0 \mathrm{~cm}$.

'Piatã' remained superior to the other cultivars when sown at $7 \mathrm{~cm}$ depth. When comparing the sowing depths for this same cultivar, a difference was only observed between the seeding depths of 0 and $10 \mathrm{~cm}$. However, for the depths of 4 and 7, there was no difference for this same variable. Also, in the seeding depth of $7 \mathrm{~cm}$, the cultivars Xaraés, Ruziziensis and Mombaça presented ESI of 0.74 , being $69 \%$ lower than sowing at $0 \mathrm{~cm}$ (that soil surface).

At the $10 \mathrm{~cm}$ depth, the ESI was practically null for Urochloa ruziziensis and Panicum 'Mombaça', and of 0.33 and 0.10 for Urochloa 'Piatã' and 'Xaraés', respectively.

Thus, to achieve greater germination, forage seeds should be sown superficially, that is, at $0 \mathrm{~cm}$. Deeper sowing is only indicated for 'Piatã' up to $7 \mathrm{~cm}$.

\section{Discussion}

According to Adegas et al. (2011), the Urochloa brizantha and Urochloa ruzizienses are used as mulch and for soil surface protection in no-tillage system, due to its long duration, high biomass production and complete adaptation to the Cerrado.

According to Hessel et al. (2012) when compared to major crops, pastures seeds present low physiological quality, which can be attributed to the unevenness of seed maturity in the plant. The Normative Instruction no. 30 (Brazil, 2008) establishes that for commercialization, the forage seeds must have minimum germination of $40 \%$. In this sense, only 'Piatã' meet the standards required by the legislation. This low germination is possibly attributed to seed 2017/2018 lot, being recommended for sowing in 2017/2018. To ensure adequate plant population, growers should adopt the appropriate cultivar, and be aware of the seed lot and the sowing depth.

For Lopes and Franke (2010), Sena, Alves, and Medeiros (2015), the evaluation of seed vigor can be performed indirectly in the field through the first count of emerged seedlings. Reductions in the emergence speed, emergence unevenness and initial seedling size can be associated to seed deterioration.

Silva and Argenta (2000) report that increased sowing depth stimulates the expansion of the mesocotyl further so the plant growth point and the first stem knots are located at a relatively constant distance from the soil surface. Forage grasses have small seeds with low amount of endosperm reserves, so sowing depth may be a limiting factor in the germination and development of the seedlings, which makes this factor relevant in crop settling (Rezende et al., 2012).

Regarding the germination of Panicum 'Mombaça', the results of this research differ from those obtained by Melo et al. (2016) that verified germination between 57 to $89 \%$ in a study on seeds physiological quality. Ikeda 
et al. (2103) found delay in the emergence of $U$. brizantha, $U$. brizantha 'Piatã' at seeding depth of $0 \mathrm{~cm}$. However, at this depth, no reduction in height and dry mass production of plants was observed.

Santos et al. (2011) testedng different types of seeds of Urochoa 'Piatã' and obtained ESI of 1.31, 2.86 and 5.44 in laboratory tests and ESI of $0.64,0.89$ and 1.70 in field test. These authors also obtained, for emergence in the field seven days after sowing, $11 \%$ for high purity seeds, $7.75 \%$ for seeds coated with plaster polymers and fertilizers; and 34\% for scarified seeds.

For Lago and Martins (1998), the seeds of Urochoa spp. presented difficulties in germinating in the laboratory and in the field; and the main contributing factor is the occurrence of seed dormancy. Santos et al. (2015) studied the initial growth of Urochloa species as a function of sowing depth, and verified for the forages $U$. brizantha 'Piatã', U. brizantha and U. ruziziensis that the ideal seeding depth is $2.10,3.61$ and $3.67 \mathrm{~cm}$, respectively. Deeper seeding of 4, 6 and $8 \mathrm{~cm}$ of depth reduce the ESI and directly affect the biomass production.

Pacheco et al. (2010) tested the seeding depth and initial growth of forages $U$. brizantha, $U$. decumbens, $U$. ruziziensis and Panicum maximum, and observed that plants develop better when sown at depths of up to $1 \mathrm{~cm}$. They also verified that ESI was reduced from sowing at $8 \mathrm{~cm}$ depth. All tested species presented viability in emergence at sowing on the soil surface, that is, at $0 \mathrm{~cm}$, except Brachiaria decumbens. These authors do not recommend planting deeper than $4 \mathrm{~cm}$ for $P$. maximum, as it does not germinate at greater depths.

According to Rezende et al. (2012) sowing depth varies between species and low germination efficiency when sowing is carried out in deep layers may result in low forage production and, consequently, contribute to the failure of livestock activity. Still according to these authors, although there is emergence in greater depth, $10 \mathrm{~cm}$, many seedlings cannot reach the surface, dying from depletion of seed reserves.

\section{Conclusions}

Seeding at $0 \mathrm{~cm}$ provides greater seedlings emergence in forages Urochloa brizantha 'Piatã', Urochloa brizantha 'Xaraés', Urochloa ruziziensis and Panicum maximum 'Mombaça'.

Seedling emergence reduced when sowing was performed at greater depths $(4,7$ and $10 \mathrm{~cm})$.

If necessary, Urochloa brizantha 'Piatã' should be sown up to $7 \mathrm{~cm}$.

The sowing should not be performed at $10 \mathrm{~cm}$ depth.

\section{References}

Adegas, F. S., Voll, E., \& Gazziero, D. L. P. (2011). Manejo de plantas daninhas em milho safrinha em cultivo solteiro ou consorciado à braquiária ruziziensis. Pesquisa Agropecuária Brasileira, 46(10), 1226-1233. https://doi.org/10.1590/S0100-204X2011001000016

Andrade, A. F. M. D., Amaral Sobrinho, N. M. B. D., Santos, F. S. D., Magalhães, M. O. L., Tolón-Becerra, A., \& Lima, L. D. S. (2014). EDTA-induced phytoextraction of lead and barium by brachiaria (B. decumbens $\mathrm{cv}$. Basilisk) in soil contaminated by oil exploration drilling waste. Acta Scientiarum Agronomy, 36(4), 495-500. https://doi.org/10.4025/actasciagron.v36i4.18172

MAPA (Ministério da Agricultura, Pecuária e do Abastecimento). (2008). Instrução Normativa $n^{\circ} 30$, de 21 de maio de 2008 (p. 45). Diário Oficial da União, Brasília, DF, 23 maio 2008.

MAPA (Ministério da Agricultura, Pecuária e do Abastecimento). (2009a). Regras para análise de sementes (p. 399). Brasília: SDA/ACS.

Chioderoli, C. A., Mello, L. M. M., Grigolli, P. J., Silva, J. O. R., \& Cesarin, A. L. (2010). Consorciação de braquiárias com milho outonal em plantio direto sob pivô central. Engenharia Agrícola, 30(6), 1101-1109. https://doi.org/10.1590/S0100-69162010000600011

EMBRAPA. (1999). Centro Nacional de Pesquisa de Solos. Sistema brasileiro de classificação de solos (p. 412). Brasília, Embrapa Serviço de Produção de Informação.

Euclides, V. P. B., Montagner, D. B., Barbosa, R. A., Valle, C. B., \& Nantes, N. N. (2016). Animal performance and sward characteristics of two cultivars of Brachiaria brizantha (BRS Paiaguás and BRS Piatã). Revista Brasileira de Zootecnia, 45(3), 85-92. https://doi.org/10.1590/S1806-92902016000300001

Foloni, J. S. S., Custódio, C. C., Pompei, F. P., \& Viva, M. R. (2009). Instalação de espécie n forrageira em razão da profundidade no solo e contato com fertilizante formulado NPK. Pesquisa Agropecuária Tropical, 39(1), $7-12$. 
Geier, R. P. J., Sprey, M. M., Silva, W. P., \& Santos, E. R. (2018). Qualidade de sementes de capim piatã submetidas a diferentes períodos de contato com fertilizantes NPK. Revista Científica Tribus da Amazônia, $1,30-41$.

Hessel, C. L. E., Vieira, R. D., \& Mendonça, L. D. (2012). Mesa densimétrica e qualidade Fisiológica de sementes de brachiária. Informativo Abrates, 22(3), 73-76.

Ikeda, F. S., Victoria Filho, R., Vilela, L., Marchi, G., Cavalieri, S. D., \& Silva, A. A. (2013). Emergência e crescimento inicial de cultivares de Urochloa em diferentes profundidades de semeadura. Planta Daninha, 31(1), 71-78. https://doi.org/10.1590/S0100-83582013000100008

Lago, A. A., \& Martins, L. (1998). Qualidade fisiológica de sementes de Brachiaria brizantha. Pesquisa Agropecuária Brasileira, 33(2), 199-204.

Lopes, R. R., \& Franke, L. B. (2010). Teste de condutividade elétrica para avaliação da qualidade fisiológica de sementes de azevém (Lolium multiflorum L.). Revista Brasileira de Sementes, 32(1), $123-130$. https://doi.org/10.1590/S0101-31222010000100014

Maguire, J. D. (1962). Speed of germination-aid in selection an devaluation for seed linge mergence and vigor. Crop Science, 2(1), 176-177. https://doi.org/10.2135/cropsci1962.0011183X000200020033x

Melo, L. F, Martins, C. C, Silva, G. Z., Boneti, J. E. B. \& Vieira, R. D. (2016) Beneficiamento na qualidade física e fisiológica de sementes de capim-mombaça.. Revista Ciência Agronômica, 47(4), 667-674.

Mendonça, V. Z., Mello, L. M. M., Andreotti, M., Pereira, F. C. B. L, Lima, R. C, Valério Filho, W. V., \& Yano, E. H. (2013). Avaliação dos atributos físicos do solo em consórcio de forrageiras, milho em sucessão com soja em região de cerrados. Revista Brasileira Ciências do Solo, 37, 251-9. https://doi.org/10.1590/ S0100-06832013000100026

Oliveira, P., \& Scivittaro, W. R. B. (2007). Formação do porta-enxerto Trifoliata: época de semeadura e tegumento na emergência de plântulas. Ciência Rural, 37(1), 281-283. https://doi.org/10.1590/S0103-84782 007000100047

Pacheco, L. P., Pires, F. R., Monteiro, F. P., Procópio, S. O., Assis, R. L., \& Petter, F. A. (2010). Profundidade de semeadura e crescimento inicial de espécies forrageiras utilizadas para cobertura do solo. Ciência e Agrotecnologia, 34, 1211-1218. https://doi.org/10.1590/S1413-70542010000500019

Rezende, A. V., Andrade, L. P., Almeida, G. B. F., Rabelo, C. H. S., Rabelo, F. H. S., Landgraf, P. R. S., ... Vilela, H. H. (2012). Efeito da profundidade e da mistura de sementes ao adubo químico na emergência de plântulas de espécies forrageiras. Revista Agrarian, 5(16), 115-122.

Santos, L. D. C., Benett, C. G. S., Silva, K. S., \& Silva, L. V. (2011). Germinação de diferentes tipos de sementes de Brachiaria brizantha cv. Piatã. Biosci. Journal, 27(3), 420-426.

Santos, E. R., Barros, H. B., Capone, A., Melo, A. V., Cella, A. J., \& Santos, W. R. (2012). Divergência genética entre genótipos de soja com base na qualidade de sementes. Rev. Bras. Ciênc. Agrárias, 7(2), $247-254$. https://doi.org/10.5039/agraria.v7i2a1560

Santos, F. L. S., Melo, W. R. F., Coelho, P. H. M., Benett, C. G. S., \& Dotto, M. C. (2015). Crescimento inicial de espécies de Urochloa em função da profundidade de semeadura. Revista de Agricultura Neotropical, 2(4), 1-6. https://doi.org/10.32404/rean.v2i4.685

Sena, D. V. A., Alves, E. U., \& Medeiros, D. S. (2015). Vigor de sementes de milho cv. 'Sertanejo' por testes baseados no desempenho de plântulas. Ciência Rural, 45(11), 1910-1916. https://doi.org/10.1590/0103$8478 \mathrm{cr} 20120751$

Shanmuganathan, V., \& Benjamin, L. R. (1992). The Influence of Sowing Depth and Seed Size on Seedling Emergence Time and Relative Growth Rate in Spring Cabbage (Brassica oleracea var. capitata L.). Annals of Botany, 69(3), 273-276. https://doi.org/10.1093/oxfordjournals.aob.a088340

Silva, P. R. F., \& Argenta, G. (2000). Ecofisiologia e fenologia das culturas do milho e do sorgo. In J. M. B. Parfitt (Ed.), Produção de milho e sorgo na várzea (pp. 7-18). Pelotas: Embrapa Clima Temperado.

Silva Filho, J. P. (2018). Plantio de sementes forrageiras. Retrieved from http://www.diadecampo.com.br/ zpublisher/materias/Materia.asp?id=20636\&secao=Sementes $\% 20 \mathrm{e} \% 20 \mathrm{Mudas}$

Zuffo, A. M., Andrade, F. R., Silva, L. M. A., Menezes, K. O., Silva, R. L., \& Piauilino, A. C. (2014). Profundidade de semeadura e superação de dormência no crescimento inicial de sementes de Brachiaria 
dictyoneura (Fig. \& De Not.) Stapf (1919) cv. Llareno. Revista Ceres, 61(6), 948-955. https://doi.org/ 10.1590/0034-737X20146106009

\section{Copyrights}

Copyright for this article is retained by the author(s), with first publication rights granted to the journal.

This is an open-access article distributed under the terms and conditions of the Creative Commons Attribution license (http://creativecommons.org/licenses/by/4.0/). 